\title{
KOHTI VERKKOMAINETTA: KÄSITYKSIÄ ORGANISAATION VERKKOVIESTINNÄSTÄ MAINEEN RAKENTAJANA
}

\begin{abstract}
Artikkelissa pohditaan organisaation maineenhallinnan ja verkkoviestinnän välisiä ybteyksiä. Tarkastelun keskiössä ovat ybtäältä teoriavetoinen pohdinta maineen rakenteesta ja toisaalta organisaatioviestinnän ammattilaisten näkemykset verkkoviestinnän vaikutusmahdollisuuksista mainetta määrittäviin organisationaalisiin tekijöihin ja maineen tuottamiin byötyihin organisaatiolle. Keskeiseksi nousee kysymys viestinnän vaikutuksista, mikä tässä ybteydessä rajautuu toteutuneiden vaikutusten sijaan organisaatioviestinnän ammattilaisten vaikutusarvioibin. Artikkeli esittelee havaintoja tutkimuksesta, jonka tarkoituksena on selventää viestinnän ammattilaisten vallitsevia käsityksiä maineen ja verkon vaikutussubteista, vaikutuksista maineen rakennetekijöibin ja potentiaalisiin mainebyötyibin. Ensin esitellä̈̈n kirjallisuudesta ja aiemmasta tutkimuksesta johdettu käsitteellinen tarkastelukebys verkkoviestinnän ja maineen rakentumisen ja byötyjen välisistä subteista. Tämän jälkeen tarkastellaan kyselytutkimuksella kerätyn aineiston mä̈rällisellä analyysillä, miten viestinnän ammattilaisten näkemykset subteutuvat tarkastelukehikon sisältämiin propositioiksi muotoiltuibin väitteisiin.
\end{abstract}

Maineen ja maineenhallinnan käsitteet ja käytännöt ovat viime aikoina nousseet organisaatiotutkimuksen ja organisaatioviestinnän tutkimuksen kiinnostuksen kohteeksi. Samoin verkkoviestintä ja sen monet johdannaiset ovat kiinnittäneet tutkijoiden huomion. Yritysten mainetta on tutkittu muun muassa taloudellisen menestymisen (Fombrun 1996; Aula \& Mantere 2008), kilpailukyvyn (Davies ym. 2003), yhteiskuntavastuun (Willmott 2001), kulttuuristen representaatioiden (Karvonen 1999) ja esimerkiksi riskienhallinnan (Larkin 2003) ja merkityksen mittaamisen (Fombrun \& Van Riel 2004; Caruana ym. 1995; Caruana 1997; Lewis 2001) näkökulmista. Eritoten viimeaikoina mainekeskustelu on levinnyt yritystä koskevan puheen ulkopuolelle. Mainetta, sen rakentumista ja merkitystä onkin tutkittu paitsi yritysten, myös muiden organisaatioiden ja yhteisöjen näkökulmasta. Tarkastelun kohteena on ollut esimerkiksi julkishallinnon organisaatioiden (Luoma-aho 2007), korkeakoulujen (Vidaver-Cohen 2007) ja maiden maine (Passow ym. 2005) sekä esimerkiksi kaupunkien maineen rakentuminen kaupunkikuvan ja omakohtaisten kaupunkia koskevien

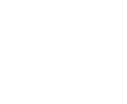

Tiedotustutkimus 2008:4

$31: 4,63-77$ 
kokemusten vuoropuheluna (Aula ym. 2007; Aula \& Harmaakorpi 2008). Mainetutkimuksen kasvavana kiinnostuksen kohteena on uusi viestintäteknologia, eritoten internet (esim. Park \& Lee 2007) ja sen suhde organisaatioiden viestintään tai suhdetoimintaan (Walsh 2003). Kun internet käsitetään enemmän organisaation merkitysympäristönä kuin viestinnän kanavana (ks. Aula $\&$ Vapaa 2006), oleellista on mainekäsitys, jonka mukaan maine kehkeytyy kerronnallisesti rakentuvista sosiaalisista todellisuuksista (Deetz 1986).

\section{VERKKOVIESTINTÄ JA MAINEENHALLINTA: EMPIIRINEN TARKASTELUKEHIKKO}

Käsityksiä verkkoviestinnän vaikutuksista organisaatioiden maineeseen voidaan lähestyä yhtäältä maineen rakenteen ja toisaalta saavutettavien, mahdollisten maine-etujen näkökulmasta. Edellinen viittaa verkossa tapahtuvaan maineenhallintaan, jolloin organisaatio pyrkii verkkoviestinnällään vaikuttamaan organisaatiosta tehtyihin tulkintoihin ja erilaisiin arviointeihin. Jälkimmäinen olettaa, että hyvä maine tuottaa organisaatiolle hyötyjä ja että nämä hyödyt konkretisoituvat hyvän maineenhallinnan seurauksena.

\section{Maine rakenteena}

Maineen rakenteen näkökulmasta maineen operationalisointi lähtee oletuksesta, että kohdetta arvioidaan tiettyjen sitä koskevien ominaisuuksien tai tekijöiden kautta (Fombrun \& Shanley 1990). Arvioimme, ja siten "maineellistamme", organisaation esimerkiksi sen mukaisesti, miten katsomme sitä johdettavan, minkälaisia sen tuotteet ja palvelut ovat tai miten arvioimme sen strategian pätevyyttä. Maine voidaankin operationalisoida Pekka Aulan ja Jouni Heinosen (2002, ks. myös Aula \& Mantere 2005) maineen rakennetta kuvaavan "mainepyörän" mukaisesti. Siinä maineen katsotaan rakentuvan kuuden ulottuvuuden mukaan, joita kutakin määrittää neljä ala-attribuuttia. Nämä maineen kuusi ulottuvuutta koskevat organisaation kulttuuriin ja johtamiseen, tuotteisiin ja palveluihin, menestykseen, yhteiskuntavastuuseen, julkiseen kuvaan sekä muutos- ja kehityskykyyn liittyviä tekijöitä (Aula \& Heinonen 2002). Maineen rakennemallin (mainepyörä) perusteella voimme esittää ensimmäisen proposition $\left(\mathrm{P}_{1}\right)$ verkkoviestinnän ja maineenhallinnan välisistä suhteista.

$\mathrm{P}_{1}$ : Verkkoviestinnällä voidaan vaikuttaa myönteisesti organisaation maineen rakenteeseen.

Maineesta katsotaan olevan sekä aineellista että aineetonta hyötyä organisaatioille (ks. esim. Grunig \& Chun-ju 2002; Rindova, Pollock \& Hayward 2006). James Grunig (2002) toteaa, että maineenhallinnan arvo organisaatioille on ennen kaikkea sidosryhmäsuhteissa. Grunigin mukaan mainetta ei voi hallita suoraan, mutta siihen voidaan vaikuttaa esimerkiksi sillä, miten yrityksen johto käyttäytyy suhteessa sidosryhmiin. Hyvä maine on siten seurausta organisaatio-sidosryhmä -suhteista ja niiden onnistumisesta. Maine-etuja voidaan konkretisoida suhteen, position ja sosiaalisen pääoman käsitteiden avulla. 


\section{Maine suhteena}

Luottamusta voidaan pitää organisaation ja sidosryhmän välisten suhteiden yhtenä perustana (Aula \& Mantere 2005). Hyvän suhteen muita tunnusmerkkejä ovat sitoutuminen (March \& Simon 1958), tunne aidosta kumppanuudesta ja uskottavuus (Mahon \& Wartick 2003). Siten maineen rakentumiselle on edullista, että organisaation ja sen sidosryhmien välillä vallitsee luottamus, osapuolet ovat sitoutuneita ja suhteen toimijat ovat uskottavia.

Verkon nähdään olevan hyvä väline sidosryhmäsuhteiden rakentamiseen esimerkiksi dialogisen viestinnän näkökulmasta (Kent \& Taylor 1998). Dialogisen viestinnän keskeisen ajatuksen mukaisesti organisaation verkkoviestinnällä voidaan vaikuttaa siihen, missä määrin sidosryhmät pitävät organisaatiota tärkeänä nykyisenä ja tulevana yhteistyökumppanina. Uskottavuuden näkökulmasta oleellista on, että verkkoviestinnällä voidaan vaikuttaa siihen, kuinka asiantuntevina meidän organisaatiotamme pidetään.

Nämä oletukset maineenhallinnan ja sidosryhmäsuhteiden laadun välisistä kytköksistä voidaan muotoilla toiseksi verkko-maineenhallinnan propositioksi $\left(\mathrm{P}_{2}\right)$.

$\mathrm{P}_{2}$ : Verkkoviestinnällä voidaan parantaa sidosryhmäsuhteiden

laatua ja siten vahvistaa maineelle edullisia sidosryhmäsuhteita.

\section{Maine positiona}

Maine on jotain, mitä puhutaan, kerrotaan, mainitaan (Smythe ym. 1992). Siten maineeseen liittyy aina viestinnällinen ulottuvuus (maineen kommunikaatioperiaate) ja maineenhallinnan yhtenä perustehtävänä on pyrkiä vaikuttamaan siitä käytäviin keskusteluihin myös organisaation sidosryhmien keskinäisissä verkostoissa. Toisaalta maineeseen liittyy kohteestaan aina jonkinlainen laadullinen arviointi (Fombrun 1996). Tämä maineen evaluointi-periaate korostuu useissa maineen mittaamisen tekniikoissa, joissa sidosryhmiä pyydetään arvioimaan tiettyjä organisaatiota koskevia tekijöitä (esim. van Riel \& Fombrun 2007). Lisäksi maineen katsotaan erottavan kohteen toisesta vastaavasta (Fombrun 1996; Fombrun \& van Riel 2004). Tämä maineen erotteluperiaate vaikuttaa, kun organisaatiota arvottava tekee päätöksiä yhden hyväksi toisen kustannuksella, ja toimii siten "yrityksen nimissä" kertoessaan valinnoistaan muille (Aula \& Vapaa 2006, 220).

Maineenhallinnalla organisaatio pyrkii vaikuttamaan siitä rakentuviin kulttuurisiin presentaatioihin (Geertz 1973), jotka vaikuttavat edelleen suotuisiin toimintaedellytyksiin (Karvonen 1999). Siten maineen periaatteiden mukaisen verkkoviestinnän voidaan ajatella tuottavan organisaatiolle viesteihin, arvioihin ja erottautumiseen pohjaavia positiointi-etuja suhteessa muihin toimijoihin. Kun nämä maineen periaatteet sovelletaan verkkoviestinnän ja maineen suhteisiin, saadaan verkko-maineenhallinnan kolmas propositio $\left(\mathrm{P}_{3}\right)$.

$\mathrm{P}_{3}$ : Verkkoviestinnällä voidaan saavuttaa maineen positiointietuja suhteessa muihin organisaatioihin. 
Maine-etuja voidaan tarkastella myös aineettoman omaisuuden karttumisen kautta (Cornelissen \& Thorpe 2002), jolloin maine voidaan käsitteellistää esimerkiksi sosiaalisen pääoman avulla (Carow 1999; Petrick ym. 1999).

\section{Maine sosiaalisena pääomana}

Organisaatiotutkijat käyttävät usein sosiaalisen pääoman käsitettä viitatessaan Pierre Bourdieun (1986) käsityksiin ei-taloudellisen pääoman muodoista (Aula \& Mantere 2008). Strategiaa tutkineiden Janine Nahapietin ja Sumatra Ghoshalin (1998) mukaan organisaation sosiaalisessa pääomassa on kolme ulottuvuutta. Sosiaalisen pääoman rakenteelliseen ulottuvuuteen liittyy organisaation käytössä oleva sosiaalinen verkosto, jolla viitataan joko organisaation viralliseen suhdetoimintaan tai sen henkilöstön, yleensä sen johdon, henkilökohtaisiin suhteisiin. Relationaalinen sosiaalinen pääoma käsittelee sitä, millainen organisaation suhde toisiin verkoston jäseniin on laadultaan. Sen rakennusaineita ovat ennen kaikkea luottamus, mutta myös yhteinen identifikaatio, yhteiset normit, keskinäiset sopimukset ja muut verkoston keskinäisiä suhteita määrittelevät sosiaaliset ilmiöt. Sosiaalisen pääoman kognitiivinen ulottuvuus liittyy organisaation kulttuurilliseen ja symboliseen pääomaan, johon kuuluvat verkostossa toimijoiden jakama kieli, yhteiset tarinat ja merkitykset. Pelkkä verkostossa oleminen ei siten riitä, eivätkä myöskään sinänsä asianmukaiset välit sidosryhmiin - tarvitaan myös kyky viestiä tehokkaasti (ks. Aula \& Mantere 2005).

Organisaation maine rakentuu sen sidosryhmien muodostamissa verkostoissa liikkuvista tarinoista ja muista jaetuista merkityksistä (ks. Aula \& Mantere 2008). Sikäli maine on voimakkaasti osa organisaation sosiaalis-kognitiivista pääomaa. Toisaalta maineeseen liittyvät myös luottamus ja muut relationaalisen pääoman piirteet - hyvään maineeseen ei riitä, että organisaatio tunnetaan; hyvä maine tarkoittaa, että organisaation luotetaan ja samastutaan. Maineen käsitteellistäminen sosiaalisen pääoman avulla johtaa neljänteen propositioon $\left(\mathrm{P}_{4}\right)$.

$\mathrm{P}_{4}$ : Verkkoviestinnällä voidaan saavuttaa maineen sosiaalisen pääoman rakentumisen etuja.

Neljästä esitetystä propositiosta ja niiden oletetuista keskinäisriippuvuuksista rakentuu verkkoviestinnän ja maineen välisten yhteyksien empiiristä tarkastelua alustava viitekehys, jossa keskeisiä ulottuvuuksia ovat maineen rakenne ja maine-edut määritettynä maine-suhteena (organisaation ja sidosryhmien välisten suhteiden laatu eli luottamus, sitoutuminen, uskottavuus), maineen positiointina (tarinat, arviointi, erottuminen) ja sosiaalisen pääoman rakentumisena (rakenteellinen, kognitiivinen, relationaalinen).

\section{ORGANISAATIOVIESTINNÄN AMMATTILAISET MAINEEN RAKENTAJANA}


via vuorovaikutusprosesseja, joissa ihmiset luovat, ylläpitävät, käsittelevät ja muokkaavat merkityksiä (Aula 1999). Vastaavasti maineen kerronnallista tai tulkinnallista luonnetta korostavasta näkökulmasta (ks. Aula \& Mantere 2008) organisaatio voi viestinnällään osallistua organisaatiota koskevien todellisuuksien tuottamiseen, jotka heijastavat organisaation omien jäsenten tulkintaa itsestään ja ympäristöstään. Esimerkiksi "tiedottaminen" ei ole vain tiedon siirtoa vaan osallistumista organisaation rakentumista ohjailevaan keskusteluun ja merkitysten muodostumiseen. Viestinnän ammattilaisten työ on siten aina kannanotto organisaatiota ympäröivässä merkitysympäristössä (Aula \& Mantere 2008), jolloin organisaation omat kannat esimerkiksi sosiaalisen median palveluissa voivat tukea maineen rakennusta.

Organisaatioviestinnän keskeinen rooli organisaatiomaineen rakentumisprosesseissa osaltaan perustelee viestinnän ammattilaisten näkemysten valikoitumista tutkimuksen kohteeksi. Näkemyksiä koskeva tarkastelu on mielekästä myös siksi, että viestinnän ammattilaisten käsityksillä on merkitystä käytännön kannalta: näkemykset viestinnän keinoista ja vaikutuksista vaikuttavat siihen, miten he viestintätyönsä tekevät. Lisäksi, ja ehkä hieman praktisemmalta kannalta, viestinnän ammattilaisten näkemyksillä nähdään olevan merkitystä, sillä verkkoviestinnän rooli on viestinnän ammattilaisten asiantuntijatason työssä keskeinen ja "yhteisöviestintää ovat viime vuosina leimanneet uuden viestintätekniikan ja verkkoviestinnän tuomat muutokset" (Yhteisöviestintätutkimus 2007, 98). Oleellista on myös, että maine ja maineenhallinta ovat uusia käsitteitä organisaatioviestinnässä ja vasta juurtumassa viestintäprofession käsite- ja työkalupakettiin eikä tutkimustietoa viestinnän ja maineenhallintaa koskevista käsityksistä juuri ole. Lisäksi näkemykset verkkoviestinnän ja maineenhallinnan välisistä merkityssuhteista ovat jatkuvan debatin kohteena, mikä edelleen vahvistaa käsitystä myös empiirisen tutkimuksen tarpeesta.

\section{AINEISTO JA MENETELMÄT}

Tutkimuksen poikkileikkausaineisto kerättiin internet-kyselynä syksyllä 2007. Helsingin yliopiston käytössä olevassa e-lomake-palvelussa toteutettuun kyselyyn lähettiin sähköpostikutsu Viestinnän ammattilaiset ProCom ry:n jäsenille (1618 jäsentä 2007), joista 433 vastasi. Vastanneiden profiili (sukupuoli, ikä, asema) vastasi hyvin ProComin jäsenprofiilia (Yhteisöviestintätutkimus 2005). Esimerkiksi naisten osuus vastanneista (89 \%) vastaa kohtuullisen hyvin naisten osuutta viestintäammattilaisissa, mikä vuosina 2005 ja 2007 oli 84 prosenttia (Yhteisöviestintätutkimus 2005; 2007).

Kyselylomake rakentui edellä esitetyn viitekehyksen osioista johdetuista 31 kysymyksestä. Kysymysosiot koskivat siis maineen rakennetta ja maine-etuja (suhde, periaatteet, sosiaalinen pääoma). Osioiden kysymykset olivat väitteiden muodossa, kuten "Organisaation verkkoviestinnällä voimme vaikuttaa siihen, minkälaisia arvioita sidosryhmämme tekevät organisaatiomme johtamisesta ja organisaatiokulttuurista". Kaikkiin kysymyksiin vastattiin viisiportaisella asteikolla, jolloin esimerkiksi verkkoviestinnän vaikutuksia koskevissa väittämissä arviointiskaala oli $1-5$, joita 5 = "sopii erittäin hyvin" ja 1 = "sopii erittäin huonosti”.

Tiedotustutkimus 2008:4 
Vastaajia opastettiin verkkoviestinnän määrittelyssä siten, että lomakkeen johdannossa annettiin seuraava määritelmä: "Verkkoviestinnällä tarkoitetaan organisaation viestinnän teknologioita ja teknologian välittämiä sisältöjä, joita organisaatio käyttää kommunikoidessaan sidosryhmiensä kanssa. Verkkoviestinnän muotoja ovat muun muassa internet (www, kotisivut), sähköposti, erilaiset pikaviestimet (esim. messenger), intranet, blogit, mobiilit viestintäverkot." (ks. Aula ym. 2006; Aula \& Jokinen 2007.)

\section{HAVAINTOJA VERKKOVIESTINNÄN VAIKUTUSMAHDOLLISUUKSISTA MAINEESEEN}

Yhtäältä tutkimuksen tarkoituksena oli saada yleiskuva siitä, mitä viestinnän ammattilaiset ajattelevat verkkoviestinnän ja maineenhallinnan välisistä suhteista. Toisaalta tarkoitus oli pohtia kyseessä olevan ryhmän käsityksiä siitä, miten verkkoviestinnällä voidaan vaikuttaa yhtäältä maineen rakenteeseen ja missä määrin verkkoviestinnällä voidaan saavuttaa organisaatiolle mainehyötyjä. Samalla selvitettiin, kuinka hyvin tai huonosti tutkitun ryhmän käsitykset vastaavat kirjallisuudesta johdettua mallia verkkoviestinnän vaikutuksista.

Taulukko 1. Verkkoviestinnän vaikutukset maineen rakennetekijöibin (keskiarvo ja -hajonta)

\begin{tabular}{|l|l|l|l|}
\hline & $\mathrm{n}$ & $\mathrm{ka}$ & $\mathrm{sd}$ \\
\hline Tuotteet ja palvelut & 432 & 4.71 & .526 \\
\hline Julkinen kuva & 432 & 4.48 & .667 \\
\hline Menestyminen & 430 & 4.05 & .812 \\
\hline Yhteiskuntavastuu & 432 & 4.05 & .871 \\
\hline Muutos- ja kehityskyky & 429 & 4.02 & .883 \\
\hline Johtaminen ja kulttuuri & 431 & 3.80 & .933 \\
\hline
\end{tabular}

Verkkoviestinnällä nähdään olevan merkittävä vaikutus maineen rakenteen eri osa-alueisiin. Taulukossa 1 keskiarvoina esitetyt vaikutusmahdollisuudet osoittavat, kuinka eniten vaikutusta nähdään olevan organisaation tuotteista ja palveluista $(\mathrm{ka}=4.71)$ ja julkisesta kuvasta $(\mathrm{ka}=4.48)$ tehtyihin arvioihin. Seuraavaan ryhmään kuuluvat organisaation menestykseen $(\mathrm{ka}=4.05)$, vastuullisuuteen $(\mathrm{ka}=4.05)$ ja muutos- ja kehityskykyyn $(\mathrm{ka}=4.02)$ liittyvät mainetekijät. Kaikkein vähiten vaikutusta verkkoviestinnällä ajatellaan olevan johtamiseen ja kulttuuriin liittyviin tekijöihin $(\mathrm{ka}=3.80)$. Tätä voidaan tulkinta niin, että verkkoviestinnän vaikutukset nähdään suuriksi, kun niitä arvioidaan suhteessa organisaation ulkoisia suhteita vahvistaviin tekijöihin. Tuotteet ja palvelut ovat juuri tämänkaltainen organisaation ja sen sidosryhmien välinen keskeinen, suhteellisen konkreettinen rajapinta. Sen sijaan arviointien tekeminen organisaation sisäisistä tekijöistä, kuten johtamiseen ja organisaatiokulttuuriin liittyvistä tekijöistä, on ymmärrettävästi hankalampaa. Tätä osoittaa esimerkiksi juuri johtamiseen ja kulttuurin liittyvän mainetekijän suuri keskihajonta $(\mathrm{sd}=0.933)$. Johtamisesta ja kulttuurista tehdyissä arvioissa on siis eniten vaihtelua. 
Taulukko 2. Maineen etuja mittaavat muuttujat (keskiarvo ja -hajonta)

\begin{tabular}{|l|l|l|l|}
\hline & $\mathrm{n}$ & $\mathrm{ka}$ & $\mathrm{sd}$ \\
\hline Distinktio & 430 & 4.15 & .719 \\
\hline Uskottavuus & 430 & 4.11 & .667 \\
\hline Tunnettuus & 431 & 4.06 & .727 \\
\hline Kommunikaatio & 427 & 3.86 & .826 \\
\hline Sitoutuminen & 430 & 3.73 & .736 \\
\hline Narratiivisuus & 429 & 3.67 & .842 \\
\hline Luottamus & 431 & 3.62 & .776 \\
\hline Hyvyys & 429 & 3.61 & .795 \\
\hline Evaluatiivisuus & 426 & 3.41 & .822 \\
\hline
\end{tabular}

Viestinnän ammattilaisten mielestä verkkoviestinnällä voidaan saavuttaa maine-etuja, mutta etuja koskevat arviot vaihtelevat maineen rakennetekijöitä koskevia arvioita enemmän. Kiinnostavia ovatkin taulukossa 2 keskiarvoina esitetyt arviot, joiden mukaan arvioinneissa näyttäisi olevan rakennetekijöitä kriittisempi ote huolimatta voittopuolisesti positiivisesta suhtautumisesta maine-etujen eri tekijöihin. Eniten verkkoviestinnällä nähtiin oleva niin sanottua distinktio-etuja, millä viitataan verkkoviestinnän potentiaaliin vaikuttaa organisaation erottautumiskykyyn esimerkiksi kilpailijoista tai kumppaneista. Vähiten vaikutusmahdollisuuksia on organisaatiosta tehtäviin laadullisiin arviointeihin (evaluatiivisuus-etu). Luottamusta kuvaavan maine-edun asema on myös erityisen kiinnostava. Verkkoviestinnän ei siis nähdä vaikuttavan kovinkaan vahvasti luottamuksen rakentumiseen. Tällä on erityistä merkitystä, sillä juuri luottamuksen nähdään olevan aikamme hyviä sidosryhmäsuhteita määrääviä tekijöitä (ks. Aula \& Mantere 2006) ja luottamusta voidaan pitää myös organisaatioiden verkkotiedon merkittävyyden yhtenä peruspilarina.

Vaikka verkkoviestinnän vaikutusarvioiden tarkastelu yksittäisten maineen rakenne- ja etutekijöiden suhteen antaa viitteitä verkon todellisesta vaikutuspotentiaalista, syvällisempää kuvaa varten tarvitaan lisäanalyysiä. Miten verkkoviestinnän nähdään vaikuttavan maineen kokonaisrakenteen (mainepyörä) tekijöihin ja maineen etuihin, kuten aiemmin kirjatussa tarkastelukehikossa pohdittiin? Kokonaiskuvan saamiseksi muodostettiin niin sanotut summamuuttujat maineen rakennetta ja etuja mittaavista muuttujista. Summamuuttujia käytetäänkin usein juuri asenneväittämiin saatujen vastausten yhdistämisessä. Summamuuttujat rakennettiin aiemmin esitetyn viitekehyksen mukaisesti mittaamaan verkkoviestinnän vaikutuksia maineen rakenteeseen ja maine-etuihin. Summamuuttujien keskiarvo- ja hajonta sekä summamuuttujien reliabiliteettia kuvaava Cronbachin alfa $(\alpha)$ on esitetty taulukossa 5. Cronbachin $\alpha$ on kaikissa yli 0.7, mitä voidaan pitää hyväksyttävänä (Nunnally 1978).

Taulukon 3 ensimmäinen rivi osoittaa, kuinka verkkoviestinnän vaikutukset maineen rakenteeseen arvioitiin merkittävimmäksi $(\mathrm{ka}=4.19 ; \mathrm{sd}=.55)$. Vaikutuksen sosiaalisen pääoman rakentumiseen $(\mathrm{ka}=3.84)$ ja maineen perusperiaatteisiin $(\mathrm{ka}=3.82)$ arvioitiin suunnilleen samansuuruisiksi.

Taulukon viimeinen rivi havainnollistaa, kuinka vähiten vaikutusta nähdään olevan mainesuhteen laatuun. Arviot verkkoviestinnän mahdollisuuksista 
organisaatioiden maineenhallintaan näyttäisivät siis olevan vahvat. On kuitenkin huomattava, että viestinnän ammattilaisten demografia-rakenteen tietystä homogeenisuudesta huolimatta näkemykset verkkoviestinnän vaikutuksista voivat vaihdella merkittävästikin.

\section{VERKKOMAINE-ASENTEET}

Verkkoviestintänäkemysten erojen selvittämiseksi vastaajat luokiteltiin ryhmiin käyttäen ryhmittely- eli klusterianalyysiä. Klusterianalyysi on monimuuttujamenetelmä, jolla aineisto pyritään jakamaan sisällöllisesti yhtenäisiin ryhmiin haluttujen muuttujien perusteella. Lisäksi jatkotarkastelussa käytettiin apuna edellä mainittuja summamuuttujia.

Kiinnostuksen kohteena oli nimenomaan, miten vastaajat ryhmittyvät suhteessa asenteisiin verkkoviestinnän maineenhallinnan mahdollisuuksista. Koska

Taulukko 3. Verkkoviestinnän vaikutukset maineen rakenteeseen ja maine-etuibin.

\begin{tabular}{|c|c|c|c|c|}
\hline & $\mathrm{n}$ & $\mathrm{ka}$ & $\mathrm{sd}$ & Cronbachin alfa \\
\hline $\begin{array}{l}\text { Verkkoviestinnän vaikutukset } \\
\text { maineen rakenteeseen } \\
\text { Johtaminen ja kulttuuri, yhteiskun- } \\
\text { tavastuu, tuotteet ja palvelut, julki- } \\
\text { nen kuva, menestyminen, muutos- } \\
\text { ja kehityskyky. }\end{array}$ & 427 & 4.19 & .551 & .79 \\
\hline $\begin{array}{l}\text { Verkkoviestinnän vaikutukset } \\
\text { sosiaalisen pääoman rakentumiseen } \\
\text { Vaikutukset siihen, kuinka hyvin } \\
\text { organisaatio tunnetaan, kuinka } \\
\text { hyvin se viestii ja kuinka hyvänä } \\
\text { organisaatiota pidetään. }\end{array}$ & 425 & 3.84 & .627 & .72 \\
\hline $\begin{array}{l}\text { Verkkoviestinnän vaikutukset } \\
\text { maineen positiointi-etuihin } \\
\text { Vaikutukset organisaatiosta kier- } \\
\text { täviin tarinoihin, sidosryhmien } \\
\text { kriittiseen suhtautumiseen ja siihen, } \\
\text { miten hyvin organisaatio pystyy } \\
\text { erottumaan muista vastaavankal- } \\
\text { taisista organisaatioista, kuten kil- } \\
\text { pailijoista. }\end{array}$ & 429 & 3.82 & .629 & .70 \\
\hline $\begin{array}{l}\text { Verkkoviestinnän vaikutukset } \\
\text { mainesuhteen laatuun } \\
\text { Vaikutukset sidosryhmien arvostuk- } \\
\text { seen ja luottamukseen (luottamus) } \\
\text { ja siihen, että sidosryhmät pitävät } \\
\text { organisaatiota tärkeänä kumppa- } \\
\text { nina tulevaisuudessakin (sitoutu- } \\
\text { minen) sekä kuinka asiantuntevina } \\
\text { organisaatiota pidetään (uskotta- } \\
\text { vuus). }\end{array}$ & 423 & 3.74 & .631 & .83 \\
\hline
\end{tabular}


tutkimuksen kysymysmuoto oli väittämä, voidaan kokonaistasolla puhua verkkomaine-asenteesta, jolla siis tarkoitetaan asennoitumista verkkoviestinnän mahdollisuuksiin maineen rakennetekijöiden suhteen eli verkkomaineenhallintaan. Siten ryhmittelyperusteeksi valittiin juuri maineen rakennetta koskevat kuusi muuttujaa. Ryhmittelyanalyysiin käytettiin ei-hierarkkista K-keskiarvon ryhmittelyanalyysiä. Analyysi löysi kolme toistaan eroavaa ryhmää, jotka nimettiin verkkoviestinnän ja maineenhallinnan välisiä yhteyksiä kuvaavan asenteen mukaan superuskovaisiksi (42 \%), myönteisiksi (46 \%) ja epäilijöiksi (12 \%).

Superuskovaiset uskovat verkkoviestinnän mainevaikutuksiin kritiikittömästi. Ryhmä uskoo, että verkkoviestinnällä voidaan vaikuttaa vahvasti kaikkiin maineen osa-alueisiin. Myös myönteiset uskovat verkkoviestinnän mainevaikutuksiin, mutta eivät aivan yhtä varauksetta. Epäilijät sen sijaan tarkastelevat verkkoviestinnän mahdollisuuksia epäluuloisesti, jopa kriittisesti. Erityisen kiinnostavaa on, että niin sanotuista perinteisistä taustamuuttujista (sukupuoli, asema, organisaation henkilöstömäärä) vain erot sukupuolittain tarkasteltuna olivat tilastollisesti merkittäviä ( $\mathrm{p}=.028)$, mikä tarkoittaa, että sukupuoli määrittää asennoitumista verkkoviestinnän voimaan maineen rakentajana. Naisista vähän yli 40 prosenttia on superuskovaisia ja yli 40 prosenttia myönteisiä. Vain kymmenisen prosenttia naisista kuuluu epäilijöihin. Miehissä tilanne on toinen. Verrattuna naisiin, selkeästi pienempi osa (32\%) miehistä kuuluu superuskovaisiin. Kiinnostavaa on, että miehistä melkein joka neljäs (23\%) on epäilijöitä.

Taulukko 4. Varianssi-analyysi (Anova)

$\begin{array}{lrrr} & \begin{array}{r}\text { Verkkoviestinnän } \\ \text { vaikutukset } \\ \text { sosiaalisen pääoman }\end{array} & \begin{array}{r}\text { Verkkoviestinnän } \\ \text { vaikutukset } \\ \text { maineen }\end{array} & \begin{array}{r}\text { Verkkoviestinnän } \\ \text { vaikutukset } \\ \text { mainesuhteen }\end{array} \\ \text { rakentumiseen } & \text { positiointi-etuihin } & \text { laatuun } \\ \text { e-maine-asenne } & 4,08 & 4,11 & 3,95 \\ \text { Superuskovaiset } & 3,75 & 3,71 & 3,67 \\ \text { Myönteiset } & 3,38 & 3,24 & 3,24 \\ \text { Epäilijät } & & & \\ \text { Anova } & 33,30 & 55,79 & 29,86 \\ \text { F-testi } & \mathrm{p}<0,001 & \mathrm{p}<0,001 & \mathrm{p}<0,001 \\ \text { p-arvo } & , 137 & , 209 & , 126 \\ \text { Eta }^{2} & & & \end{array}$

Taulukossa 4 kuvatun yksisuuntaisen varianssi-analyysin (Anova) tulokset vahvistavat verkkomaine-asenteen ja maine-etujen tilastollisen riippuvuuden $(\mathrm{p}<.001)$. Tämä lujittaa havainnon, että superuskovaiset näkevät verkkoviestinnän tuovan enemmän maine-etuja kuin epäilijät. Samalla se osaltaan todentaa maineen eri tekijöiden ja hyötyjen välisen keskinäisriippuvuuden. Eli mitä enemmän vastaajat uskovat verkkoviestinnän rakennevaikutuksiin, sitä enemmän viestinnän nähdään tuottavan myös sosiaalista pääomaa, positiointi-etuja ja parantavan organisaation ja sidosryhmien välisen mainesuhteen laatua. 


\section{MAINE ON MONIULOTTEINEN JA HERKKÄ MUUTTUMAAN}

Aiemmin esitetty summamuuttujatarkastelu rakentaa kokonaiskuvaa verkkoviestinnän vaikutusnäkemyksistä maineeseen ja sen tuottamiin etuihin. Tarkastelun ongelmana on sen oletus eri tekijöiden korreloimattomuudesta keskenään. Toisin sanoen tarkastelu ei huomioi eri tekijöiden välisiä keskinäisiä riippuvuussuhteita. On kuitenkin perusteltua olettaa, että todellisuudessa nämä eri tekijät ovat toisistaan riippuvaisia.

Jotta nämä riippuvuudet voidaan huomioida, aineiston analyysi täydennettiin niin sanotulla rakenneyhtälömallitarkastelulla (structural equation modelling). Rakenneyhtälömallien avulla voidaan tutkia, miten hyvin jokin esitetty teoreettinen malli sopii aineistoon. Ideana on tarkastella eri tekijöiden välisiä kausaalisuhteita. Erityisen pätevä rakenneyhtälömalli on niin sanottujen latenttien muuttujien välisten yhteyksien tarkastelussa (esim. Jöreskog \& Sörbom 1979), mikä tässä tutkimuksessa tarkoittaa aiemmin esiteltyjen summamuuttujien Maine (verkkoviestinnän vaikutukset maineen rakenteeseen), Suhde (vaikutukset mainesuhteen laatuun), Positiointi (vaikutukset maineen positiointi-etuihin) ja Sosiaalinen pääoma (vaikutukset sosiaalisen pääoman rakentumiseen) välisten suhteiden analysointia. Rakenneyhtälömallin ratkaisu on esitetty kuvassa 1.

Kuva 1 Maineen rakenteen ja maine-etuja kuvaavan rakenneybtälömallin ratkaisu $\left(x^{2}=242.30, d f=81, p=.000, R M S E A=.064, C F I=.93\right)$.

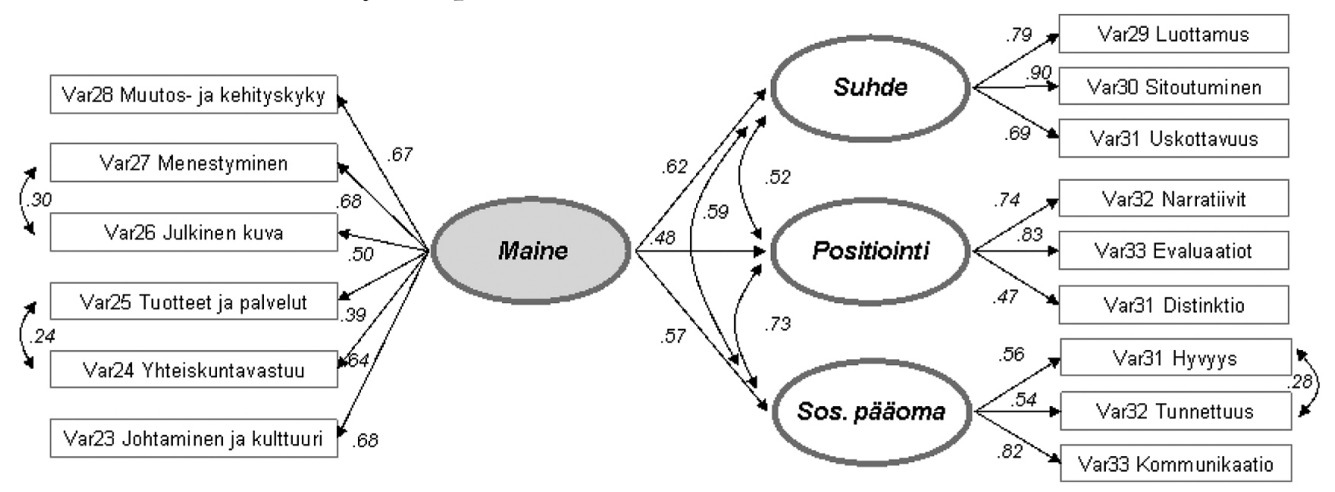

Alustavan tarkastelun jälkeen mallin sopivuutta aineistoon tutkittiin niin sanottujen modifikaatioindeksien (modification index) kautta. Analyysissä mallia modifioidaan niin, että samaa latenttia muuttujaa mittaavien indikaattorien annetaan korreloida keskenään niissä tapauksissa, joissa se on mittausteoreettisesti perusteltua. Esimerkiksi latentin muuttujan "sosiaalinen pääoma" "hyvyys" ja "tunnettuus" indikaattorien jäännöstermit korreloivat positiivisesti $(\mathrm{r}=.28)$. Tämä voi johtua esimerkiksi siitä, että "hyvyys" ja "tunnettuus" mittaavat jotain muutakin yhteistä muuttujaa kuin "sosiaalista pääomaa". Tällaisia jäännöstermien välisiä korrelaatioita on estimoitu mallissa yhteensä kuusi kappaletta: kaikissa tapauksissa jäännöstermien välillä havaittiin positiivinen korrelaatio ${ }^{1}$.

Tämän lisäksi huomattiin, että latenttien muuttujien "suhde", "positiointi" ja "sosiaalinen pääoma" jäännöstermit korreloivat keskenään. Tämä ei ole yllättävää, sillä näihin kolmeen muuttujaan vaikuttava yhteinen kolmas tekijä ("maine") selittää vain osan muuttujien välisistä korrelaatioista. Esimerkiksi muuttu- 
jat "suhde" ja "positiointi" korreloivat yhä melko vahvasti $(\mathrm{r}=.52)$ vielä senkin jälkeen, kun yhteisen tekijän "maine" vaikutus on kontrolloitu. Tästä voimme tehdä johtopäätöksen, että vaikka muuttujalla "maine" on suhteellisen vahva yhteys kaikkiin kolmeen muuhun muuttujan, se ei kuitenkaan tyhjentävästi selitä kaikkea näiden kolmen tekijän välisistä riippuvuuksista.

Kuvan 1 analyysistä voidaan tehdä johtopäätös, että yhteydet muuttujasta "maine" kaikkiin kolmeen muuhun muuttujaan ovat merkittäviä. Myös faktorilataukset ovat suhteellisen korkeita, jolloin mittauksen reliabiliteetti tai validiteetti ei ole ongelma. Lisäksi tulosten luotettavuuden kannalta keskeistä on, että mallin sopivuutta aineistoon kuvaavan RMSEA arvon (0.064) perusteella sopivuus on melko hyvä. Yleensä $0.050-0.060$ väliä pidetään mallin sopivuuden kannalta hyvänä arvona. Luotettavuutta nostaa CFI arvo (0.93), joka osoittaa mallin melko hyvää sopivuutta (tavallisesti hyvä sopivuus CFI>.95).

Rakenneyhtälömallitarkastelu vahvistaa ajatusta mallista, jonka mukaan verkkoviestinnällä nähdään olevan vaikutusta yhtäältä maineen rakenteeseen ja toisaalta verkkoviestinnällä voidaan tuottaa merkittäviä maine-etuja. Rakenneyhtälömalli osoittaa, kuinka maine, jota sinänsä voidaan pitää niin sanottuna latenttina monoliittisena ilmiönä, assosioituu sellaisiin tekijöihin, kuten "johtaminen ja kulttuuri" tai "yhteiskuntavastuu". Kuvassa 1 olevien maineen ja sen rakennetekijöiden faktorilatausten tarkastelu puolestaan osoittaa, että nämä heijastukset ovat samanaikaisia.

Käytännössä rakenneyhtälömallitarkastelu tarkoittaa, että maineestaan huolta pitävien organisaatioiden on aiheellista kohdistaan maineenrakennuksen toimenpiteet lähtökohtaisesti kaikkiin maineenosatekijöihin. Mainetta tulee siis kohdella kokonaisvaltaisesti ja esimerkiksi viidestä alueesta huolehtiminen ei välttämättä riitä; kuudennen laiminlyöminen voi osoittautua maineriskiksi. Kiinnostavalla tavalla analyysi vahvistaa erään maineen yleisen periaatteen: Hyvän maineen rakentaminen kestää pitkään, mutta sen voi menettää yhdessä yössä (ks. Aula \& Heinonen 2002). Samalla analyysi selittää, kuinka sidosryhmien mielissä olevat heijastumat ovat keskinäisriippuvia. Kun koemme tietyn organisaation palvelut huonoiksi, olemme herkästi valmiit uskomaan organisaation olevan huono myös muilla alueilla. Rakenneyhtälömalli osoittaa myös, että mainerakenteen parantaminen on positiivisesti yhteydessä maine-etuihin. Kuvassa olevat mainerakenteen ja maine-etujen välisen suhteen regressiokertoimet ovat yhtäl̈lä kukin suhteellisen vahvoja ja toisaalta positiivisia.

\section{LOPUKSI: KOHTI E-MAINEENHALLINNAN MALLIA}

Aineiston määrällisen analyysin pohjalta voidaan tarkastella aiemmin esitettyjen verkkoviestinnän ja maineen kytköksiä kuvaavien, maineen teoriasta johdettujen propositioiden mielekkyyttä. Propositiot esittivät:

- Verkkoviestinnällä voidaan vaikuttaa myönteisesti organisaation maineen rakenteeseen

- Verkkoviestinnällä voidaan parantaa sidosryhmäsuhteiden laatua ja siten vahvistaa maineelle edullisia sidosryhmäsuhteita

- Verkkoviestinnällä voidaan saavuttaa maineen positiointi-etuja suhteessa muihin organisaatioihin

- Verkkoviestinnällä voidaan saavuttaa maineen sosiaalisen pääoman rakentumisen etuja. 
Tulokset tukevat näitä propositioita siinä mielessä, että viestinnän ammattilaisten kokonaisvaltainen suhtautuminen verkkoviestinnän mahdollisuuksiin maineenhallinnassa ja maine-etujen saavuttamisessa näyttäytyi varsin myönteisenä. Samalla tarkastelu osoittaa, kuinka monisyisenä ilmiö maineenhallinta verkossa näyttäytyy. Vaikka verkkoviestinnän nähdään vaikuttavan maineen rakenteeseen, sen painoarvo mainetekijöittäin näyttäisi vaihtelevan; esimerkiksi vaikutusmahdollisuudet maineen johtaminen ja kulttuuri-ulottuvuuteen nähtiin muita tekijöitä varauksellisemmin. Tämä tarkoittaa, että käytännön maineenhallintaakaan ei voitane lähestyä pelkästään kokonaiskäsitetasolla. Siten myös verkkoviestinnän arviointia ja mittaamista on syytä lähestyä kyseessä oleva moniulotteisuus huomioiden.

Verkkoviestinnän maine-etuja arvioitaessa huomio kiinnittyy kahtaalle. Yhtäältä havainnot myötäilevät esimerkiksi verkon merkitystä sidosryhmäsuhteiden rakentamisessa ja mahdollisuuksia sosiaalisen pääoman kartuttamiselle ja maineen positioinnille. Toisaalta, samoin kuin maineen rakennevaikutusten kohdalla, kyseessä olevien etujen painoarvot vaihtelevat sekä sisäiseltä rakenteeltaan että suhteessa toisiinsa. Esimerkiksi luottamuksen rakentaminen verkossa voidaan nähdä ongelmallisena. Kiinnostavaa on myös havainto, että vaikka suhtautuminen verkkoviestinnän mahdollisuuksiin ryhmittelee organisaation viestinnän ammattilaisia (superuskovaiset, myönteiset, epäilijät), ei näiden ryhmien välisiä eroja voida selittää niin sanotuilla perinteisillä taustamuuttujilla, kuten ikä, asema organisaatiossa, organisaation koko tai toimiala. Ainoastaan sukupuolien väliset erot osoittautuivat tilastollisesti merkittäviksi. Alalla työskentelevät naiset näyttävät siis uskovan miehiä vahvemmin verkkoviestinnän vaikutuksiin. Tutkimus ei kuitenkaan vastaa kysymykseen tämän eron syistä.

Tutkimuksessa on myös selkeitä rajoitteita. Voidaan esimerkiksi pohtia, kuinka paljon tutkittava ryhmä vaikutti tulosten ennalta arvattavuuteen. Eikö esimerkiksi ole itsestään selvää, että viestinnän ammattilaiset näkevät verkkoviestinnällä saavutettavan organisaatiolle hyötyjä? Vastakkainen ajattelutapahan saattaisi vetää mattoa oman työn merkittävyyden alta, mikä taas voi vaikuttaa myötäsukaiseen vastaamiseen kyselyssä. Tutkimuksen pyrkimys ei kuitenkaan ollut arvioida viestinnän vaikutuspotentiaalia yleisesti ("viestintä parantaa mainetta"), vaan erityisesti verkkoviestinnän suhdetta maineen rakenteen eri tekijöihin ja mainehyötyjen eri osa-alueisiin. Tällä on erityistä merkitystä, sillä verkkoviestintä on vain yksi, mutta yhä merkittävämpi viestinnän tekijän työväline ja maineenhallinta yksi viestinnän nousevista nykyfunktioista. Siksi on tärkeää selvittää nimenomaan viestintäammattilaisten pelkän yleistyksen "viestintä on tärkeää" ylittäviä käsityksiä. Tutkimus ei myöskään todenna todellisia kausaalisuhteita verkkoviestinnän ja maineen välillä vaan tukeutuu tutkitun ryhmän käsityksiin näistä suhteista. Toisaalta tutkimuksen tarkoituksena ei ollutkaan todistaa tai olla todistamatta verkkoviestinnän faktisia vaikutuksia maineeseen, vaan minkälaisina nämä vaikutuspotentiaalit näyttäytyvät ja missä määrin erilaiset vaikutusmahdollisuudet suhteutuvat toisiinsa. Nämä varaukset mielessä voidaan lopuksi esittää muutama huomio.

Tutkimus osoittaa, että näkemykset maineen rakennevaikutuksista ja maineeduista näyttäisivät olevan toisistaan vahvasti riippuvaisia. Vaikka riippuvuudet saattavat osittain johtua kysymyksenasettelusta (esimerkiksi luottamus osana sekä suhdemuuttujia että sosiaalisen pääoman muuttujia) on riippuvuus riittävän suurta ollakseen käytännönkin kannalta merkittävää. Eli kun verkkovies- 
tinnän vaikutus maineen rakennetekijöihin kasvaa, myös maineesta kumpuavat edut vahvistuvat. Tämä vahvistaa ajatusta maineen "hyvästä kehästä" (Aula \& Heinonen 2002) ja vastaavasti huonon maineen tuomasta "kurjistumisen kierteestä" (Aula ym. 2007) ja niiden toimivuudesta myös organisaation verkkoympäristössä. Siten verkkoviestinnällinen maineenhallinta (verkkomaine) voisi tuottaa sen verran kannatettavia seurauksia, ettei organisaatioilla ole varaa ainakaan olla pohtimatta näitä tekijöitä omalta kantiltaan.

Käytännössä, eritoten rakenneyhtälömallin, analyysi siis tukee esitettyjä propositioita $\left(\mathrm{P}_{1}-\mathrm{P}_{4}\right)$. Viestinnän ammattilaiset näkevät verkkoviestinnän mahdollisuudet samankaltaisesti esitetyn käsitteellisen mallin kanssa. Onkin kiinnostavaa pohtia jatkossa tätä verkkoviestinnän vahvalta vaikuttavaa panosta organisaatioiden maineenhallinnassa. Verkkomaineen rakentumista kuvaavan mallin (e-maineenhallinnan malli) mukaan verkkoviestinnällä voitaisiin vaikuttaa maineen rakenteeseen, kun maineen katsotaan rakentuvan mainepyörän mukaisesti kuudesta tekijästä. Tämä tarkoittaa, että verkkoviestinnällä voidaan vaikuttaa sen sidosryhmien organisaation tuotteista ja palveluista, yhteiskuntavastuusta, menestymisestä, muutos- ja kehityskyvystä ja julkisesta kuvasta tekemiin arviointeihin. Samalla on kuitenkin pidettävä mielessä, että verkkoviestinnän potentiaaliset vaikutukset eivät kohdistu maineeseen kokonaisuutena vaan vaihtelevasti maineen eri rakennetekijöihin, mikä myös voisi ohjata käytännön maineenhallinnan resurssien allokointia. Toisaalta, mallin ajatuksia seuraten, verkkoviestinnällä voidaan mitä ilmeisimmin saavuttaa maine-etuja. Viestinnällä voidaan vahvistaa sidosryhmäsuhteita, positioida ja rakentaa organisaatiolle sosiaalista pääomaa. Ennen kaikkea e-maineenhallinnan malli näyttäisi konkretisoivan maineen ja maine-etujen välisen käsitteellisen suhteen. Vaikka maine rakentuu sidosryhmien arvioinneissa (ja siten organisaation "ulkopuolella"), niin mitä viestinnällisesti vahvempi organisaatio, sitä enemmän se pystyy myös internetissä vaikuttamaan siihen, millaisia tarinoita siitä on liikkeellä - ja siten siihen, pidämmekö yrityksen toimintaa hyväksyttävänä ja yritystä hyvänä (ks. Aula \& Mantere 2008). Tärkeää olisi tutkia, mitä käytännön seuraamuksia mallin mukainen verkkoviestinnän suunnittelu ja toteutus voisi saada aikaan.

\section{Viitteet}

1 Kuvan 1 tulkinnassa on huomioitava, että muuttujien "suhde","positiointi" ja "sosiaalinen pääoma" välille piirretyt korrelaatiot ovat itse asiassa niiden niin sanottujen jäännöstermien välisiä korrelaatioita, eli korrelaatioita sen jälkeen kun yhteisen kolmannen tekijän ("maine") vaikutus on kontrolloitu. Myös muuttujien "yhteiskuntavastuu" ja "tuotteet ja palvelut" sekä "menestyminen" ja "julkinen kuva" väliset korrelaationuolet tarkoittavat korrelaatiota kyseessä olevien muuttujien jäännöstermien välillä.

Kirjallisuus

Aula, Pekka (1999) Organisaation kaaos vai kaaoksen organisaatio? Dynaamisen organisaatioviestinnän teoria.. Helsinki: Loki-Kirjat.

Aula, Pekka \& Harmaakorpi, Vesa (2008) An innovative milieu - a view on regional reputation building: Case study of the Lahti urban region. Regional Studies 42: 4, 523-538.

Aula, Pekka \& Heinonen, Jouni (2002) Maine: menestystekijä. Helsinki: WSOY.

Aula, Pekka ja Saku Mantere (2005) Hyvä yritys. Strateginen maineenhallinta. Helsinki: WSOY.

Tiedotustutkimus 2008:4 
Aula, Pekka \& Saku Mantere (2008) Strategic Reputation Management. New York: Routledge.

Aula, Pekka \& Petri Vapaa (2006) Yrityksen merkeissä: internet markkinasuhteisena merkitysympäristönä. Teoksessa Aula, Pekka; Janne Matikainen \& Mikko Villi (toim.) Verkkoviestintäkirja. Helsinki: Yliopistopaino.

Aula, Pekka; Kimmo Vehkalahti \& Topiantti Äikäs (2007) Kaupunkimaine: tutkimus kaupunkien maineen rakenteesta ja siihen vaikuttavista tekijöistä. Acta nro 193, Helsinki: Kuntaliitto.

Bourdieu, Pierre (1986) The Forms of Capital. Teoksessa Richardson, John G. (toim.) Handbook for Theory and Research for the Sociology of Education, 241-258. New York: Greenwood.

Carey, James (1992) Communication as Culture. Essays on Media and Society. New York: Routledge.

Carow, Kenneth (1999) Underwriting spreads and reputational capital: An analysis of new corporate securities. The Journal of Financial Research, Spring 99: 15-28.

Caruana, Albert (1997) Corporate reputation: concept and measurement, Journal of Product $\&$ Brand Management 6: 2, 109-18.

Caruana, Albert; Leyland Pitt \& Pierre Berthon (1995) The organizational reputation concept: Its role and measurement. Working paper series. Henley Management College: Greenlands.

Cornelissen, Joep \& Richard Thorpe (2002) Measuring a Business School's reputation: Perspectives, Problems and Prospects. European Management Journal 20: 2, 72-178.

Davies, Gary (2003) Corporate Reputation and Competitiveness. London: Routledge.

Deetz, Stanley (1986) Metaphors and the discursive production and reproduction of organization. Teoksessa Thayer, Lee (toim.), Organizations-Communication: Emerging Perspectives. I. Norwood, NJ: Ablex Publishing Co.

Fombrun, Charles (1996) Reputation: Realizing Value from the Corporate Image. Boston: Harvard Business School Press.

Fombrun, Chares $\&$ Mark Shanley (1990) What's in a name? Reputation building and corporate strategy, Academy of Management Journal 33: 2, 233-258.

Fombrun, Charles \& Cees Van Riel (2004) Fame and Fortune. New Jersey: Prentice Hall.

Geertz, Clifford (1973) The interpretation of cultures: selected essays. New York: Basic Books.

Grunig, James (2002) The Value of Public Relations Can Be Found in Relationships, Only Secondarily in Reputation. Maine-magazine, 02/2002.

Grunig, James \& Flora Chun-ju (2002) The Effect of Relationships on Reputation and Reputation on Relationships: A Cognitive, Behavioral Study. Paper presented at the PRSA Educator's Academy 5th Annual International, Interdisciplinary Public Relations Research Conference, Miami, Florida.

Jöreskog, Karl \& Dag Sörbom (1979) Advances in factor analysis and structural equation models. Cambridge: Abt Books.

Karvonen, Erkki (1999) Elämää mielikuvayhteiskunnassa. Imago ja maine menestystekijöinä myöhäismodernissa maailmassa. Helsinki: Gaudeamus.

Kent, Michael \& Maureen Taylor (1998) Building Dialogic Relationships Through the World Wide Web. Public Relations Review 24: 3, 321-334.

Larkin, Judy (2003) Strategic Reputation Risk Management. Basingstoke: Palgrave Macmillan.

Lewis, Stewart (2001) Measuring corporate reputation. Corporate Communications: An International Journal 6: 1,31-35.

Luoma-aho, Vilma (2007) Neutral Reputation and Public Sector Organizations. Corporate Reputation Review 10: 2, 124.

Mahon, John F. \& Steven L. Wartick (2003) Dealing with Stakeholders: How Reputation, Credibility and Framing Influence the Game. Corporate Reputation Review 6: 1, 19-35.

March, James. G. \& Herbert Simon (1958) Organizations. New York: John Wiley \& Sons.

Nahapiet, Janine \& Sumatra Ghoshal (1998) Social Capital and Intellectual Capital, and the Organizational Advantage. Academy of Management Review 23: 2, 242-266.

Nunnally, Jum C. (1978) Psychometric theory. New York: McGraw-Hill.

Park, Namkee \& Kwan Min Lee (2007) Effects of online news forum on corporate reputation. Public Relations Review 33, 346-348.

Passow, Tanja; Rolf Fehlmann \& Heike Grahlow (2005) Country Reputation - From Measurement to Management: The Case of Liechtenstein Corporate Reputation Review 7: 4, 309-326. 
Petrick, Joseph A.; Robert. F. Scherer; James D. Brodzinski \& John F. Quinn \& M. Fall Ainina (1999) Global leadership skills and reputational capital: Intangible resources for sustainable competitive advantage. Academy of Management Executive 13: 1, 58-69.

van Riel, Cees \& Charles Fombrun (2007) Essentials of Corporate Communication. New York: Routledge.

Rindova, Violina; T. Pollock \& M. Hayward (2006) Celebrity Firms: The Social Construction of Market Popularity. Academy of Management Review 31: 1, 50-71.

Smythe, John; C. Dorward \& J. Reback (1992) Corporate Reputation: Managing the New Strategic Asset. London: Century Business.

Walsh, Terry (2003) The Reputation Vortex. Online Reputation Management. Rollinsford, NH.: Spiro Press.

Vidaver-Cohen, Deborah (2007) Reputation Beyond the Rankings. A Conceptual Framework for Business School Research. Corporate Reputation Review 10: 4, 278-304.

Willmott, Michael (2001) Citizen Brands: Putting Society at the heart of your business.

Chichester: John Wiley \& Sons.

Yhteisöviestintätutkimus (2005) Viestinnän ammattilaiset ProCom ry.

Yhteisöviestintätutkimus (2007) Viestinnän ammattilaiset ProCom ry. 